\title{
Groundwater Risk Assessment as an Impact of Land Use in the Groundwater Basin of Salatiga, Province of Central Java, Salatiga
}

\author{
Destha A. Kesuma ${ }^{1}$, Purwanto Purwanto ${ }^{2}$, Thomas T. Putranto ${ }^{2}$, Tara Puri Ducha Rahmani ${ }^{3}$, \\ Sintha Soraya Santi ${ }^{4}$
}

${ }^{1}$ Master Program in Environmental Science, School of Postgraduate Studies, Universitas Diponegoro, Semarang 50241, Indonesia

${ }^{2}$ Department of Chemical Engineering, Faculty of Engineering, Universitas Diponegoro, Semarang 50275, Indonesia

${ }^{3}$ Department of Biology, Faculty of Science \& Technology, Universitas Islam Negeri Walisongo Semarang, Semarang 50185, Indonesia

${ }^{4}$ Department of Chemical Engineering, Faculty of Engineering, Universitas Pembangunan Nasional "Veteran"

Surabaya, East Java, Indonesia

*Corresponding author:

E-mail: tara@walisongo.ac.id

\begin{abstract}
Variation of land use can affect the quality of groundwater and increase the potential for groundwater contamination. Physical environmental conditions that have a low sensitivity to contamination of groundwater, but the use of land which could potentially generate pollutants, such as industrial areas, residential, the agricultural activity can increase the risk level of contamination in the groundwater in the area. The purpose of this study is to develop a groundwater risk to contamination map in the shallow aquifer and to determine priority areas of groundwater quality monitoring in Salatiga Groundwater Basin. Groundwater risk to contamination map was prepared on aspects of land use and the degree of vulnerability of groundwater to contamination using DRASTIC methods and spatially was prepared by using Geographic Information System. Results of the assessment of risk levels obtained worth the risk index 93-204. The risk index values are grouped into five (5) classes of risk: low, low to medium, medium, medium-high, and high. The output of this research can be input for local governments in understanding the possible spread of groundwater contamination as well as choosing the right strategy for the conservation of groundwater resources in the Groundwater Basin of Salatiga.
\end{abstract}

Keywords: Risk, groundwater, pollution, land use, Salatiga

\section{Introduction}

Salatiga Groundwater Basin is one of the 19 groundwater basins situated in the administrative region of Semarang, Salatiga, and Boyolali Regency across administrative areas regencies/cities in Central Java province. The Salatiga Groundwater Basin lies largely within the KEDUNGSEPUR (Kendal, Ungaran, Semarang, Salatiga, Purwodadi) strategic areas (Local Regulation of Central Java Province Number 6 the Year 2010) and is located at a strategic point which is linking the city of Yogyakarta, Solo, and Semarang (Joglosemar). The strategic position of the region will open up great opportunities for the region to be further developed, especially for the development of the sectors of agriculture, trade and services, industry, and tourism (Wijaya \& Atmanti, 2006).

Land use activity which is undertaken by humans for purposes, such as urbanization and agriculture, can potentially be a source of groundwater contaminants that can alter and degrade groundwater quality at a value below the quality standard designation (Babiker et al., 2005). The quality of groundwater, especially shallow groundwater is extremely vulnerable to contamination due to contact with the source of contaminants at the ground surface. Fertilizers, pesticides, chemical waste, septic systems, landfills,

How to cite:

Kesuma et al.. (2020). Groundwater risk assessment as an impact of land use in the groundwater basin of Salatiga, Province of Central Java, Salatiga. $1^{\text {st }}$ International Conference Eco. Innovation in Science, Engineering, and Technology. NST Proceedings. pages 288-299. doi: 10.11594/ nstp.2020.0545 
and various other human activities can contaminate the groundwater. Groundwater contamination can occur in the scope of small areas (such as the leakage of the fuel pipe oil) or a wider area (such as the use of fertilizers on agricultural land). When the groundwater has been contaminated, it will be very difficult to be recovered.

The movement of groundwater in the aquifer is very slow so that to clean up of groundwater in the aquifer will take a very long time (Liggett \& Talwar, 2009). Therefore, vulnerability and risk assessment of groundwater against contamination are indispensable in understanding the possible spread of the contamination of groundwater and choosing the right strategy for the protection of groundwater resources. Information on the vulnerability and risk levels of groundwater against contamination in an area can be a very important consideration for the local government to arrange the decision on the restructuring and development of the territory in the region.

Groundwater vulnerability itself according to Lathamani, et al., (2015) is the sensitivity of the aquifer system to damage due to external influences. The principle of groundwater vulnerability implies that the physical system is capable of shielding groundwater from the impact of nature or humans' activities. Earth materials can be a natural filter against contaminants that pass through it (Todd, 1980; Vrba \& Zoporozec, 1994).

Ferreira (1997) in Widyastuti, Notosiswoyo, and Anggayana (2006) have given different understandings of the term vulnerability of groundwater against contamination and the risk of contamination. The risk of contamination of groundwater includes the susceptibility level of groundwater, which is static, and the existence of sources of contaminants that are dynamic. Thus, the risk of groundwater contamination is based on the existence of potential pollutant factors (sources of pollution) of groundwater on the surface and the ability to infiltrate and reach the water-saturated zone.

The assessment of the level of groundwater vulnerability against contamination in Salatiga Groundwater Basin has been done by Kesuma, et.al. (2017) with the DRASTIC method. DRASTIC is one of the weighting and assessment of groundwater vulnerability methods that can be applied quite extensive in several types of aquifers, such as in the basaltic rocks, sedimentary rocks, carbonate, hard rock, as well as on coastal aquifers (Brindha \& Elango, 2015). Assessment of the groundwater vulnerability in DRASTIC by using the 7 (seven) parameters, they are the depth of groundwater table (D), Recharge (R), aquifer media (A), soil media (S), topography (T), the impact of vadose zone (I), and the hydraulic conductivity (C) (Aller et al., 1987).

The value of the DRASTIC Vulnerability Index in the Salatiga Groundwater Basin was 85-1599, based on the DRASTIC method analysis. The DRASTIC Vulnerability Index values are categorized into five vulnerability levels just like in Table 1 . The classification of groundwater vulnerability is based on the calculation of the weight of each parameter and the ranking applied (Table 1) along with a chart of groundwater vulnerability (Figure 1).

Table 1 . The vulnerability class and spreading region

\begin{tabular}{|c|c|c|c|c|}
\hline No & $\begin{array}{c}\text { DRASTIC } \\
\text { Index }\end{array}$ & $\begin{array}{c}\text { Vulnerability } \\
\text { Class }\end{array}$ & Characteristic & Region \\
\hline 1 & $85-100$ & Low & $\begin{array}{l}\text { Only vulnerable in the long } \\
\text { term to conservative pollu- } \\
\text { tants when discharged or } \\
\text { leached continuously and } \\
\text { widely }\end{array}$ & $\begin{array}{l}\text { Semarang Regency: } \\
\text { The southern area of Bringin } \\
\text { District, a small part of the } \\
\text { northern part of Bancak County }\end{array}$ \\
\hline
\end{tabular}

To be continued... 


\begin{tabular}{|c|c|c|c|c|}
\hline 2 & $101-120$ & $\begin{array}{l}\text { Low to Moder- } \\
\text { ate }\end{array}$ & $\begin{array}{l}\text { Only vulnerable to con- } \\
\text { servative pollutants in the } \\
\text { long term if discharged or } \\
\text { leached continuously and } \\
\text { widely until vulnerable to } \\
\text { some pollutants, but only } \\
\text { when discharged or leached } \\
\text { continuously. }\end{array}$ & $\begin{array}{l}\text { Semarang Regency } \\
\text { The southern area of the district } \\
\text { of Getasan, a small part of the } \\
\text { southern area of the district of } \\
\text { Tengaran, the northern part of } \\
\text { Tuntang district, the southern } \\
\text { part of Bringin district, a small } \\
\text { part of the northern of Bancak } \\
\text { district } \\
\text { Boyolali Regency: district of } \\
\text { Ampel }\end{array}$ \\
\hline 3 & $121-140$ & Moderate & $\begin{array}{l}\text { Vulnerable to some pollu- } \\
\text { tants, but only when dis- } \\
\text { charged or leached continu- } \\
\text { ously. }\end{array}$ & $\begin{array}{l}\text { Semarang Regency } \\
\text { Tuntang, Pabelan, Bancak, } \\
\text { Suruh, Tengaran districts, and a } \\
\text { small area of the south part of } \\
\text { Bringin district. } \\
\text { Boyolali Regency } \\
\text { The small area of the west part } \\
\text { of Wonosegoro district } \\
\text { Salatiga City } \\
\text { Sidorejo, Tingkir, and Argo- } \\
\text { mulyo districts }\end{array}$ \\
\hline 4 & $141-150$ & $\begin{array}{l}\text { Moderate to } \\
\text { high }\end{array}$ & $\begin{array}{l}\text { Vulnerable to some pollu- } \\
\text { tants, but only when dis- } \\
\text { charged or leached con- } \\
\text { tinuously. Until vulnera- } \\
\text { ble on many pollutant } \\
\text { scenarios to many pollu- } \\
\text { tants (except those highly } \\
\text { absorbed or readily trans- } \\
\text { formed). }\end{array}$ & $\begin{array}{l}\text { Semarang Regency } \\
\text { The districts of Tengaran, } \\
\text { Pabelan, Suruh, Tuntang, Bancak, } \\
\text { and Suruh } \\
\text { The City of Salatiga } \\
\text { The districts of Tingkir, Sidorejo, } \\
\text { Argomulyo, and Sidomukti }\end{array}$ \\
\hline 5 & $151-159$ & High & $\begin{array}{l}\text { In many pollutant cases, it } \\
\text { is vulnerable to many pol- } \\
\text { lutants (except for those } \\
\text { highly absorbed or readily } \\
\text { transformed). }\end{array}$ & $\begin{array}{l}\text { Semarang Regency } \\
\text { Most of the northern part of the } \\
\text { district of Pabelan and a small } \\
\text { part of the south of the district of } \\
\text { Suruh }\end{array}$ \\
\hline
\end{tabular}




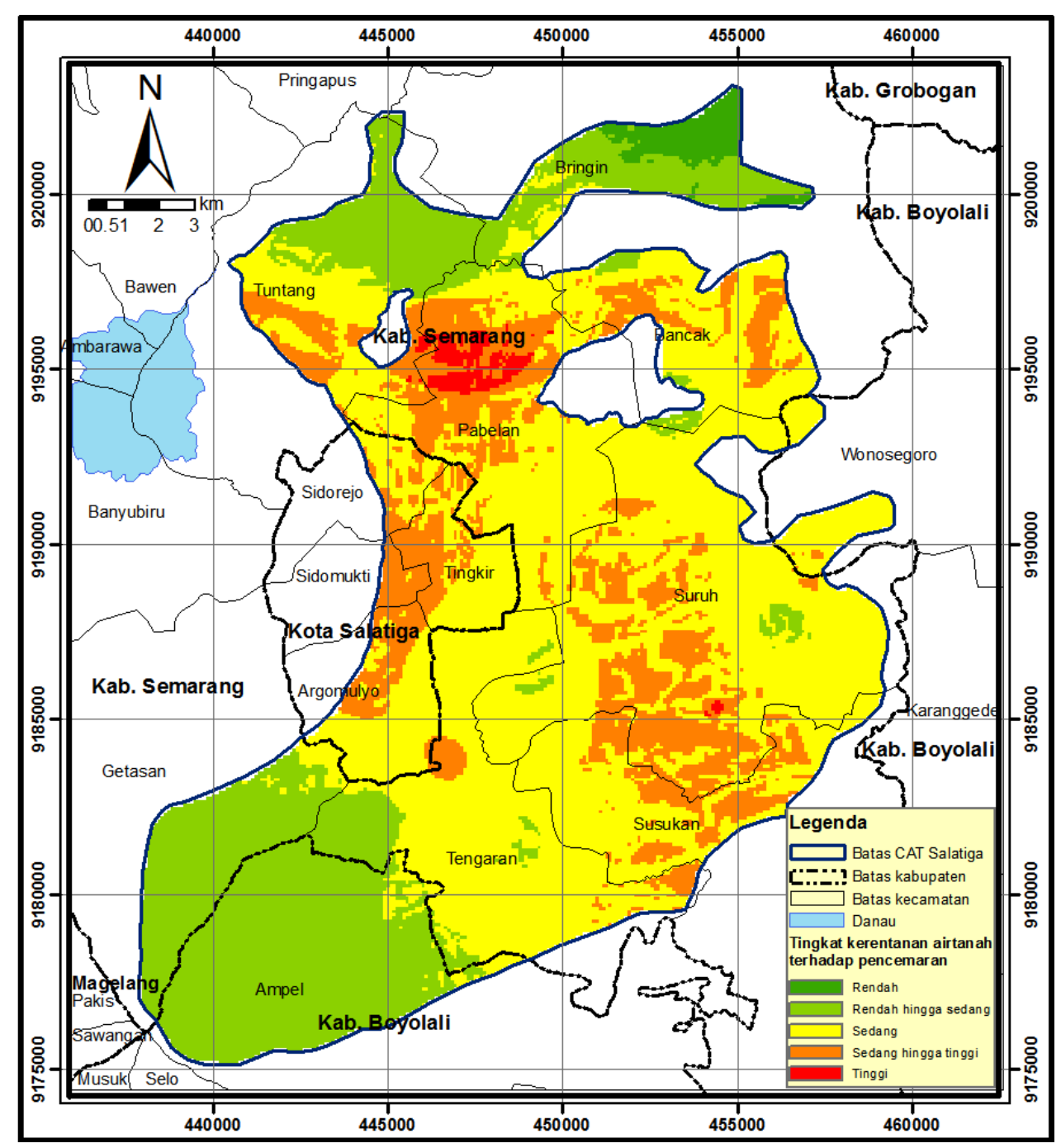

Figure 1. Map of groundwater vulnerability to contamination in Salatiga Groundwater Basin (Kesuma, et.al., 2017)

Article 13 of Protection and Management of the Environment Act, No. 32 of 2009 has mandated the implementation of pollution control and/or damage to the environment in the context of environmental conservation. Such efforts include prevention, mitigation, and recovery which are carried out by the Government, local government, and private due to each authority, roles, and responsibilities. According to Hendrayana and Putra (2008), there are three main ways to manage quality and to control groundwater pollution. They are Zoning of land use within the framework of the protection of groundwater against pollution; Controlling the source of groundwater pollution, for existing pollutant sources and the sources of pollution that potentially arise; and Creating vulnerability and risk of groundwater contamination map to determine the priority areas for controlling and/or remediating as well as the other necessary management needed. As an effort to carry out the mandate of Article 13 of Act No. 32 of 2009 to protect the quality of groundwater, so in this study was conducted the mapping of groundwater contamination risk and determined the priority areas for monitoring the quality of groundwater in the Salatiga Groundwater Basin. 


\section{Research Method \\ Location and time of research}

The research was conducted in the Salatiga Groundwater Basin region (Figure 2). Administratively, much of the Salatiga Groundwater Basin and a small portion of the Boyolali regency are included in the Salatiga and Semarang regency administrative area. Geographically, the groundwater basin of Salatiga is approximately situated between $110^{\circ} 27^{\prime} 56.81^{\prime \prime}-110^{\circ} 32^{\prime} 4.64^{\prime \prime}$ East longitude and $7^{\circ} 17^{\prime}-7^{\circ} 17.23$ 'South Latitude with an altitude between 220 and 1,450 meters above the mean level of the sea. Much of the Salatiga groundwater basin lies on the slopes of Mount Merbabu and the small mountains: Gajah Mungkur, Telomoyo, and Payung Rong, among others. (Energy and Mineral Resources of Central Java Province, 2015). The average annual rainfall over the last 5 years is approximately $2,198.33 \mathrm{~mm} /$ year (Central Bureau of Statistics at Semarang, Boyolaly, and Salatiga Regency, 2016). The research was conducted from October 2016 to January 2017 in the Salatiga Groundwater Basin area.

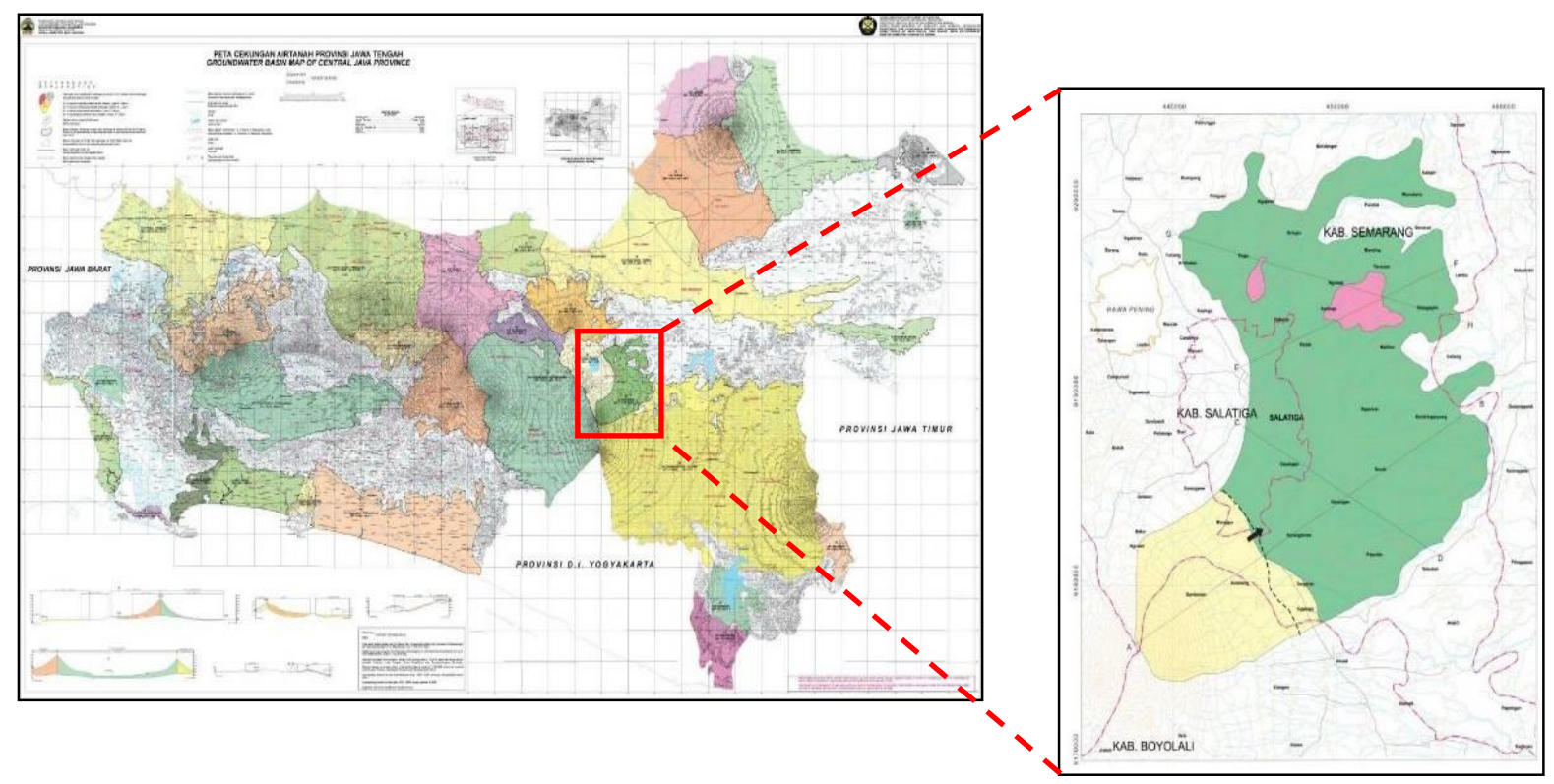

Figure 2. The Research area map in Salatiga Groundwater Basin

\section{Type of research}

This research was qualitative by scoring and weighting the parameters of land use to determine the level of risk of groundwater contamination.

\section{Data collection techniques}

The data which were used in this research was secondary:

a) Map of the vulnerability of groundwater against contamination in the Salatiga Groundwater Basin which was obtained from Kesuma, et al. (2017);

b) Spatial Plans of Salatiga Groundwater Basin Map Year 2010-2030 as well as other supporting data in the Office of Energy and Mineral Resources of Central Java Province.

\section{Data analysis techniques}

The data analysis was conducted by determining the weighting and rating of land use designation parameters which had already been specified in the Spatial Plan of Salatiga Groundwater Basin of 20102030. Aspects of land use weights 5 (Brindha \& Elango, 2015). Land use parameter values are presented in table 2 . 
Table 2. Parameter value of land use

\begin{tabular}{clc}
\hline No & \multicolumn{1}{c}{ Land Use } & Rating \\
\hline $\mathbf{1}$ & Agricultural areas & \\
& Perimeters for irrigation (annual crops, paddy fields) & 9 \\
& Permanent crops (orchards, yards of vines) & 7 \\
& Agricultural heterogeneous areas & 5 \\
& Grasslands and agro-forested regions & 5 \\
$\mathbf{2}$ & Artificial areas & 10 \\
& Discharges for industrial waste, landfills & 8 \\
& Quarries, shipyards, mining in the open air & 7.5 \\
& Continuous urban areas, airports, ports, (rail) roads, industrially or commercially & \\
$\mathbf{3}$ & productive areas, green spaces & 5 \\
& Natural areas & 0 \\
& Aquatic environments (salt marshes, Salinas, intertidal zones) & 0 \\
\hline & Semi-natural zones and forests & \\
& Bodies of Water
\end{tabular}

(Brindha \& Elango, 2015)

Geographic Information Systems (GIS) were used in performing overlaying bitmap/raster between the weighting map of land use and map of the groundwater vulnerability against contamination with the DRASTIC method, so the total value of the raster can be calculated to determine the risk index of groundwater vulnerability to contamination. The risk index was calculated using a raster calculator with the formula (Al-Hanbali \& Kondoh, 2008):

Risk index $=$ DRASTIC indeks + LUCw. LUCr

Where:

$\mathrm{LUCw}$ : weighting of land use/cover parameter

$\mathrm{LUCr}$ : the rating of land use/cover parameter

\section{Result and Discussion \\ Land use}

The land use in Salatiga Groundwater Basin according to regional spatial plans of Salatiga, Semarang, and Boyolali Regency Year 2010-2030, such as the designation of Production Forest Area, Industrial Area, Wetlands Region, Dry Land Areas, Landslide Prone Region, Annual Crop Region, Infiltration region, Settlements, and Merbabu National Park (Salatiga City Regulation No. 4/2011, Semarang Regency Regulation No. 6/2011, and Boyolali Regency Regulation No. 9/2011). The aspects of land use for the fulfillment of human needs can result in groundwater pollution sources and contribute to the entry of pollutants into groundwater. The land use which was interpreted potentially generate pollution sources in the study area were (table 3):

Table 3. Potential land use producing the source of pollutants

\begin{tabular}{lll}
\hline No & Land Use & Type of Contaminant \\
\hline 1 & Production Forest Area & nitrates; ammonium; fecal organisms \\
2 & Wetlands Region & nitrates; ammonium; pesticides; fecal organisms \\
3 & Dry Land Areas & nitrates; ammonium; pesticides; fecal organisms \\
4 & Annual Crop Region & nitrates; ammonium; fecal organisms
\end{tabular}


To be continued

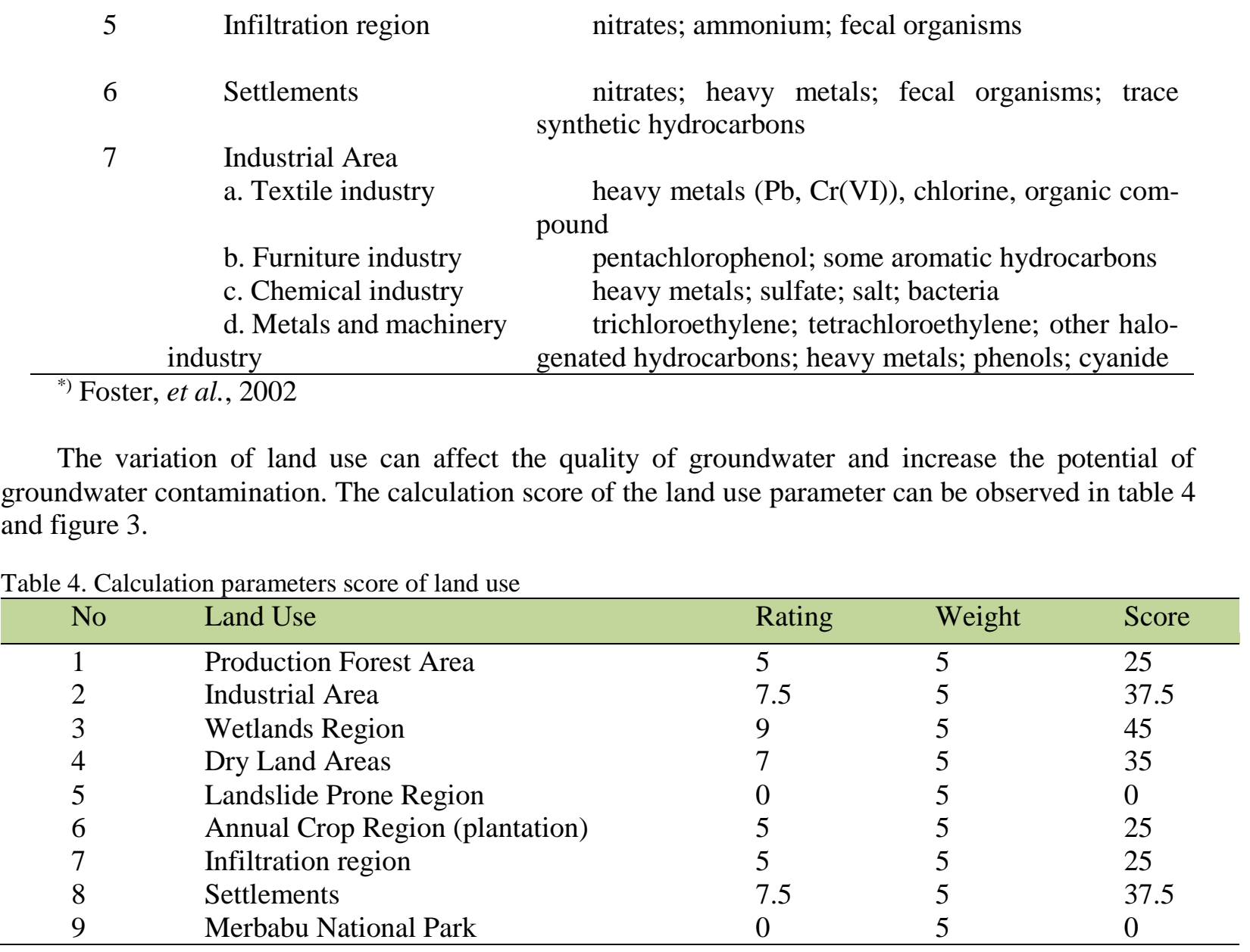

\section{Groundwater risk assessment to contamination}

Based on the results of risk analysis to contamination, the value of the risk index was 93-204. The risk index values were classified into 5 classes of risk, which are: low (93-115.2), low to medium (115.3137.5), medium (137.6-159.8), medium to high (159.9-182.1), and high (182.2-204) (Table 5 and Figure 4).

Tabel 5. Risk class to contamination and spreading region

\begin{tabular}{llll}
\hline No & Value & Risk Class & Region \\
\hline 1 & $93-115.2$ & Low & Semarang Regency: \\
& & $\begin{array}{l}\text { A small part of the western of the Bringin dis- } \\
\text { trict, and eastern part of Tuntang district, most } \\
\text { of Getasan district. } \\
\end{array}$ & \\
& & Boyolali Regency: \\
& & Most of Ampel district
\end{tabular}

2 115.3-137.5 Low to medium Semarang Regency: 
Most of Bringin, Tuntang, Suruh, Tengaran and Getasan districts

To be continued...

$3 \quad 137.6-159.8 \quad$ Medium

4

159.9-182.1 Medium to high

5
182.2-204 High

Semarang Regency:

Most of Bringin, Tuntang, Pabelan, Bancak, Suruh, Tengaran, and Getasan district

Boyolali Regency

Most of Ampel district and small part of the Wonosegoro district.

Semarang Regency:

Most of Bringin, Tuntang, Pabelan, Bancak, Suruh, and Tengaran districts

Boyolali Regency:

Most of Wonosegoro district

Salatiga City:

Sidorejo, Sidomukti, Tingkir, and Argomulyo districts

Semarang Regency:

Most of Tuntang, Pabelan, Bancak, Suruh, and

Tengaran districts

Boyolali Regency:

Small part of Wonosegoro district

Salatiga City:

Most of. Sidorejo and Tingkir districts, and small part of Argomulyo district.

Based on the risk map, the land use aspect also influence the distribution of shallow groundwater contamination risk zones in the study area. The moderate to high-level zone and the high-level zone became widespread when it was compared with the zoning map of groundwater vulnerability in the DRASTIC method. Land use such as wetlands, settlements, and industrial areas which were considered to have high enough potency to produce contaminants will increase the level of risk of groundwater contamination.

\section{Planning the location of the groundwater monitoring wells to contamination}

Determining the monitoring wells location was based on areas that have a high level of risk. The location of monitoring wells is also determined by considering the function of the public water supply monitoring because there are groundwater resources in the form of springs and dug wells that are used for the domestic needs of the population. The proposed location of monitoring wells in Salatiga Groundwater Basin can be seen in Figure 5 and Table 6.

Table 6. Proposed location of groundwater quality monitoring wells

\begin{tabular}{|c|c|c|c|c|c|c|}
\hline Code & $\begin{array}{l}\text { Coordin } \\
\text { tion } \\
X\end{array}$ & te Posi- & District & Regency/city & Land Use & Risk Level \\
\hline SP-1 & 441723 & 9196939 & Tuntang & Semarang & Settlements & high \\
\hline SP-2 & 446791 & 9195918 & Pabelan & Semarang & Settlements & high \\
\hline SP-3 & 455160 & 9195000 & Bancak & Semarang & $\begin{array}{l}\text { Settlements and } \\
\text { wetlands }\end{array}$ & high \\
\hline
\end{tabular}




\begin{tabular}{|c|c|c|c|c|c|c|}
\hline SP-4 & 445505 & 9191592 & Sidorejo & Salatiga & Settlements & high \\
\hline SP-5 & 447220 & 9190851 & Pabelan & Semarang & Settlements & high \\
\hline SP-6 & 451508 & 9188886 & Suruh & Semarang & $\begin{array}{l}\text { Settlements and } \\
\text { wetlands }\end{array}$ & high \\
\hline SP-7 & 456068 & 9185475 & Susukan & Semarang & $\begin{array}{l}\text { Settlements and } \\
\text { wetlands }\end{array}$ & high \\
\hline SP-8 & 452744 & 9183718 & Suruh & Semarang & $\begin{array}{l}\text { Settlements and } \\
\text { wetlands }\end{array}$ & high \\
\hline SP-9 & 444517 & 9185605 & Argomulyo & Salatiga & Settlements & $\begin{array}{l}\text { moderate- } \\
\text { high }\end{array}$ \\
\hline SP-10 & 444924 & 9182651 & Tengaran & Semarang & Industrial Area & $\begin{array}{l}\text { moderate- } \\
\text { high }\end{array}$ \\
\hline SP-11 & 445158 & 9180644 & Ampel & Boyolali & Industrial Area & $\begin{array}{l}\text { moderate- } \\
\text { high }\end{array}$ \\
\hline SP-12 & 447453 & 9181659 & Tengaran & Semarang & Settlements & $\begin{array}{l}\text { moderate- } \\
\text { high }\end{array}$ \\
\hline SP-13 & 456864 & 9189697 & Wonosegoro & Boyolali & $\begin{array}{l}\text { Settlements and } \\
\text { paddyfield }\end{array}$ & $\begin{array}{l}\text { moderate- } \\
\text { high }\end{array}$ \\
\hline
\end{tabular}

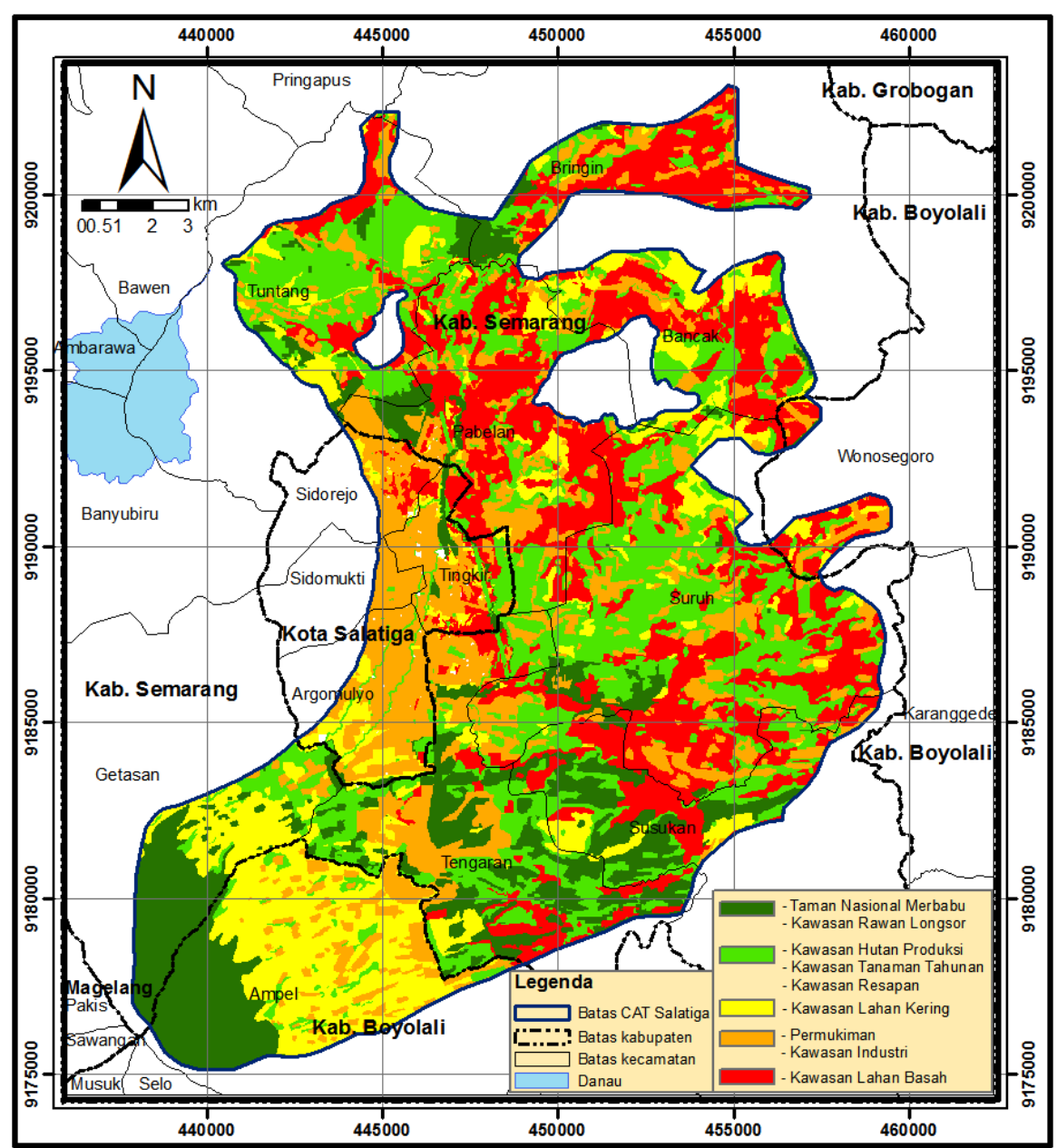

Figure 3. The weighted land use map in salatiga groundwater basin (analysis results, 2017) 


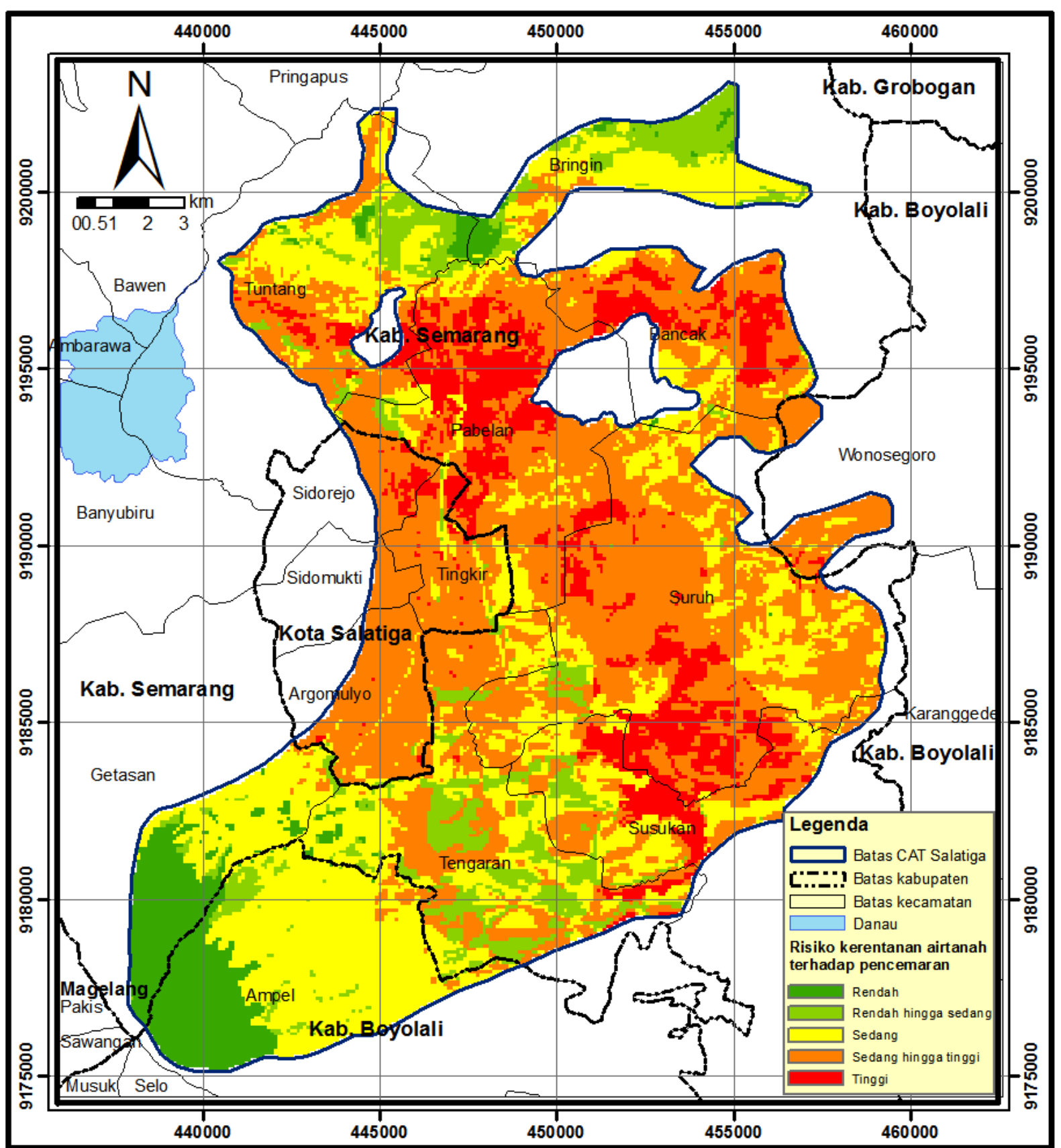

Figure 4. The Map of Groundwater Risk to Contamination in Salatiga Groundwater Basin (Analysis result, 2017) 


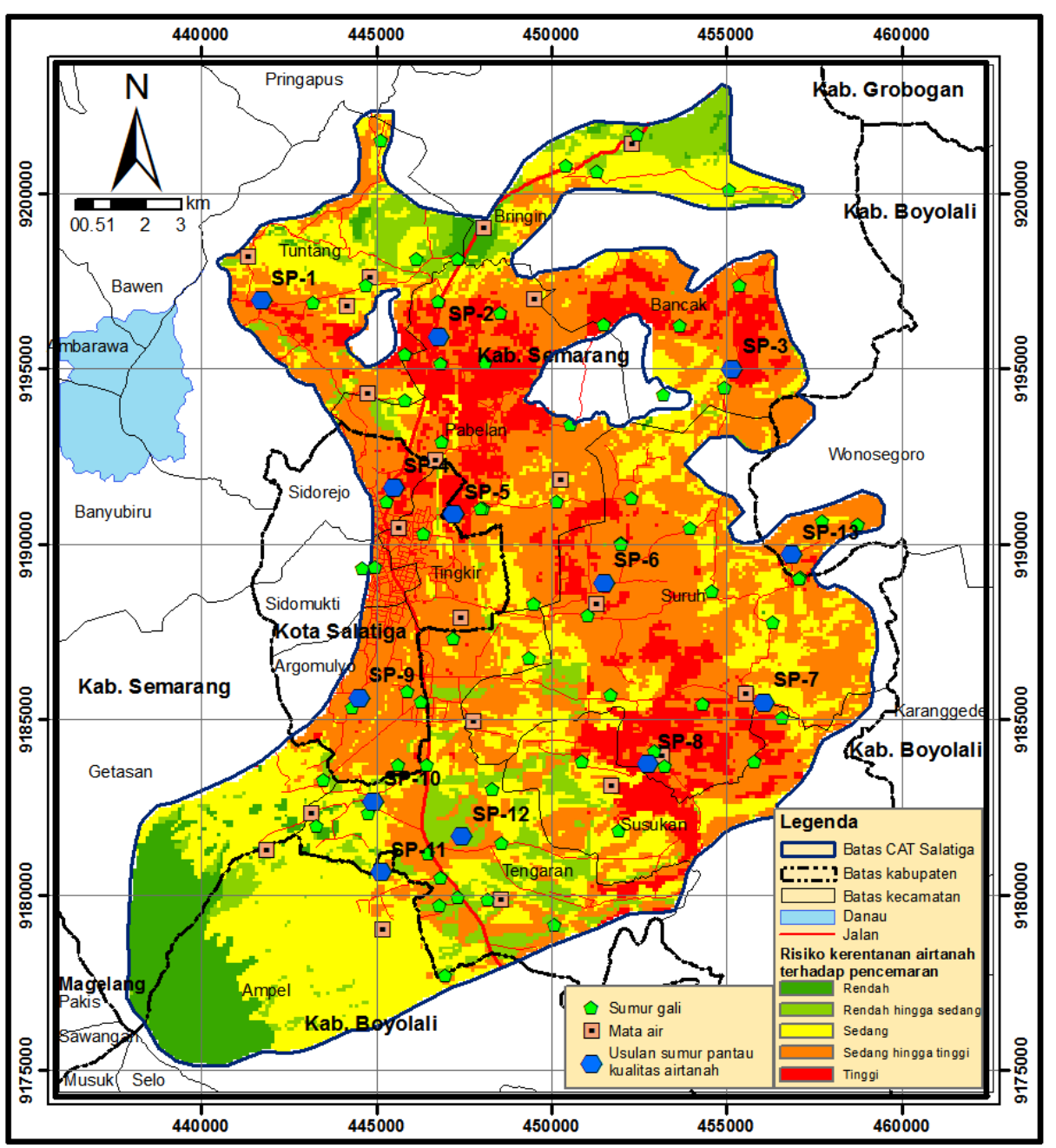

Figure 5. The map of proposed location of groundwater quality monitoring wells (Analysis result, 2017)

\section{Conclusion}

The level of risk of groundwater contamination in Salatiga Groundwater Basin was divided into five (5) zones of groundwater pollution risk levels, which are the level of low risk, low to medium, medium, medium to high, and high. Land use such as wetlands, settlements, and industrial areas have high enough potency to generate sources of pollution, so they can increase the level of risk of groundwater contamination. The Map of Groundwater Risk to Contamination can be used to determine the location of groundwater quality management priorities and devise appropriate strategies for the protection of groundwater resources in Salatiga Groundwater Basin.

\section{Acknowledgment}

PUSBINDIKLATREN BAPPENAS would like to be acknowledged by the writers for sponsoring this study. Thank you to UPN Veteran Jawa Timur for conducting the International Conference ICESET 2020. We thank you to Mrs. Titien Soetinah Alisoenhaji for the continuing support.

\section{References}

Al-Hanbali A., \& Kondoh, A. (2008). Groundwater vulnerability assessment and evaluation of human activity impact (HAI) within the Dead Sea groundwater basin, Jordan. Hydrogeol J 2008; 16:499-510, Aller, L., Bennet, T., Lehr, J. H., Petty, R. J., and Hackett, G., 1987. 
“DRASTIC: A Standardized System for Evaluating Ground Water Pollution Potential Using Hydrogeologic Settings,” US EPA Report 600/287/035, U.S. Environmental Protection Agency.

Babiker, I. S., Mohamed, M. A. A., Hiyama, T., \& Kato, K. (2005). A GIS-based DRASTIC model for assessing aquifer vulnerability in Kakamigahara Heights, Gifu Prefecture, Central Japan. Sci Total Environ, 345,127-140.

Brindha, K., \& Elango, L. (2015). Cross comparison of five popular groundwater pollution vulnerability index approaches. Journal of Hydrology, 524 (2015) 597-613.

Central Bureau of Statistics, Boyolaly Regency. (2016). Boyolali Regency in Figures. Catalog: 1102001.3309. Boyolali.

Central Bureau of Statistics, Semarang Regency. (2016). Semarang Regency in Figures. Catalog: 1102001.3322. Ungaran.

Central Bureau of Statistics, Salatiga City. (2016). Salatiga City in Figures. Catalog: 1102001.3373. Salatiga.

Central Java Province Local Regulation (PERDA) Number 6 Year 2010, regarding the Central Java Province Spatial Plans.

Energy and Mineral Resources Department of Central Java Province. (2015). Studi Sistem Jaringan Sumur Pantau Pada CAT Rawapening dan CAT Salatiga, Semarang.

Foster, S., Hirata, R., Gomes, D., D’Elia, M., \& Paris, M. (2002). Groundwater Quality Protection: a Guide for Water Utilities, Municipal Authorities and Environment Agencies. World Bank Publication: Washington D.C., USA, available at http://documents.worldbank.org/curated/en/913221468028147970/pdf/250710PUB00BOX334116B01PUBLIC1.pdf accessed at 24 th July 2016.

Hendrayana, H., \& Putra, D.P.E. (2008). Pengendalian air tanah ” sebuah pemikiran”. Jurusan Teknik Geologi - Fakultas Teknik. Universitas Gadjah $\quad$ Mada. $\quad$ Yogyakarta, $\quad$ available https://www.researchgate.net/profile/Heru_Hendrayana/publication/275964869_Pengendalian_Airtanah-

Sebuah_Pemikiran_2008_Heru_Hendrayana_Doni_Prakasa_EP/links/554c48eb0cf29752ee7edc38.pdf, accessed at 28 th December 2016.

Kesuma, D.A., Purwanto, Putranto, T.T., \& Rahmani, T. P. D. (2017). Factor weighting in DRASTIC modelling to evaluate aquifer vulnerability in salatiga groundwater basin, central java province, draft proceedings of The 3rd International Conference Planning in The Era of Uncertainty: Sustainable Nation, Universitas Brawijaya, Malang, Jawa Timur.

Lathamani, R., Janardhana, M.R., Mahalingam, B., \& Suresha, S. (2015). Evaluation of aquifer vulnerability using drastic model and GIS: A case study of mysore city, Karnataka, India, International conference on water resources, coastal and ocean Engineering (ICWRCOE 2015), Aquatic Procedia 4 (2015) 1031-1038, available at web site www.sciencedirect.com, accessed at 22 th December 2016.

Liggett, J., E., \& Talwar, S. (2009). Groundwater vulnerability assessments and integrated water resource management. Streamline Watershed Management Bulletin, 13(1), 18E29.

Protection and Management of the Environment Act of Republic of Indonesia, No. 32 of 2009.

Todd, D. K. (1980). Groundwater hydrology (2nd ed.), New York, NY: Wiley.

Vrba, J., \& Zoporozec, A. (1994). Guidebook on mapping groundwater vulnerability. International Contributions to Hydrogeology, Hannover.

Widyastuti, M., Notosiswoyo, S., \& Anggayana, K. (2006). Pengembangan Metode DRASTIC untuk Prediksi Kerentanan Airtanah Bebas Terhadap Pencemaran di Sleman. available at http://ilib.ugm.ac.id/jurnal/download.php?dataId=1903. accessed at 9 th August 2016.

Wijaya, B., \& Atmanti, H. D. (2006). Analisis pengembangan wilayah dan sektor potensial guna mendorong pembangunan di kota Salatiga. available http://eprints.undip.ac.id/16953/1/Analisis_Pengembangan_Wilayah_Dan_Sektor....by_Bayu_Wijaya_\%26_Hastarini_Dwi_Atmanti_( OK).pdf. accessed at 9 th August 2016 